\title{
Construction and Application of the Multi-intermediate Multi-media English Oral Teaching Mode
}

\author{
$\mathrm{Na} \mathrm{Li}$ \\ Shaanxi Xueqian Normal University, 710100, Xi, an, China \\ Address: 101 Shenhe 2nd Road, Chang 'an District, Xi 'an City, Shaanxi Province
}

\begin{abstract}
The study of the English language has always been a focus of education and teaching in China. The traditional English language teaching model no longer meets the needs of modern education, especially when spoken in English. Spoken English represents the actual effect of English teaching to a certain extent. Good oral English ability reflects one's English level. The traditional oral English teaching mode is only limited to the interactive training of the oral mechanization between the teacher and student, or the non-targeted dialogue training with foreign teachers, which ignores the factors such as environment, language sense and emotion. With the development of information technology, especially the advancement of computer human-computer interaction technology, it is very necessary to fully combine oral English teaching with information technology. This paper proposes a multi-interactive multi-media teaching mode based on computer technology combined with the development of oral English teaching under Chinese characteristics. The model proposed in this paper will combine the first layer of interaction in oral English teaching, that is, classroom and extracurricular teacher-student interaction, life-and-life interaction, and vital interaction and second-level interaction, namely teacherstudent emotion, context and motivation. A comparative analysis of the actual sample test of a middle school is carried out. The experimental results show that the proposed multi-interaction strategy of spoken English is more advantageous than the traditional teaching mode.
\end{abstract}

KEY WORDS: Information technology; multiple interaction strategies; oral English teaching mode.

\section{INTRODUCTION}

WITH further development of economic and technological globalization, economic and technical exchanges between countries have become more frequent, and English as the mainstream communication language has become more and more important (Ahmadian M J, 2012). English teaching in China started relatively late and related language teaching methods are relatively lacking (Ahmadian M J, 2012). With English reading and writing, you can receive a lot of training to improve or make a substantial leap but in the application of spoken English, our teaching model is tired and weak (Alshareef F M, 2016). As the most important part of the language itself, oral English is the key to communication. It is very meaningful to study the teaching mode of spoken English in such a background (Asr M, Wong A J, Fuller C D, 2017).
Research has been done on the oral English teaching mode but most of the research teaching modes are too limited to the first layer of interaction, namely the teacher-student interaction, life-and-life interaction and vitality interaction (Carruthers $\mathrm{P}$, Skead N K, Galloway K, 2012). The traditional oral English teaching mode only works in the mechanized dialogue of oral English. This phenomenon is very prominent in rural areas and even some third and fourth cities (Jiang W, Zhang J, Lv X, 2018). The disadvantage is that oral training is only a task rather than teacher-student and active communication within the heart (Kon K, Shiota M, Sakuyama A, 2017). Part of the teaching model introduced foreign teachers, which solved a teacher's problem to a certain extent but did not promptly guide and encourage students, which to some extent caused resources to be fully occupied by only a small number of highly motivated students and cannot make oral English training a full- 
featured activity (Oli A N, Nweke J N, Ugwu M C, 2013). With the development of information technology, some schools have introduced the humancomputer multi-media oral English training technology (Omitola O G, Soyele O O, Sigbeku O, 2017). Under such a teaching mode, human resources are completely replaced by machines, which relieves the pressure of teacher resources to a certain extent but it still does not consider the second level of interaction, i.e., emotional interaction and contextual interaction (Russo R, Edu A, Seta F D, 2018).

This paper proposes a multi-interactive multimedia teaching mode based on computer technology combined with the development of oral English teaching under Chinese characteristics (Shirato J, Stapleton P, 2007). The model proposed in this paper will combine the first layer of interaction in oral English teaching, that is, classroom and extracurricular teacher-student interaction, life-andlife interaction, vital interaction and second-level interaction, namely teacher-student emotion, context and motivation (Stengers H, Boers F, Housen A, 2011). A comparative analysis of the actual sample test of a middle school is carried out. The experimental results show that the proposed multiinteraction strategy of spoken English is more advantageous than the traditional teaching mode (Symeonidis C, Matsou A, Tzetzi D, 2017).

Section 2 will analyze the characteristics of the multi-interaction strategy and its mathematical model and specifically point out the problems existing in the current oral English teaching. Section 3 specifically analyzes the application strategy of the multiindividual interaction strategies in the oral English teaching mode. Section 4 will carry out a one-month strategy implementation in a middle school and compare and analyze it with traditional teaching, with a conclusion and Section 5 will summarize the multiinteraction oral English teaching mode.

\section{PROBLEMS IN THE ORAL ENGLISH TEACHING AND RESEARCH ON THE MULTIPLE INTERACTIVE STRATEGIES}

THE current oral English teaching is not subject to the traditional teaching concept and does not distinguish it from the teaching of other subjects. Spoken English is more special therefore, the current teaching mode still has many after the introduction of multimedia teaching problem. This section analyzes these issues in detail and will examine in detail the conceptual model of the multi-interaction strategy and the corresponding practical methods (Huang, D; Bai, Y; Liu, J, C, 2019).

\subsection{The Analysis of the Problems in Oral English Teaching}

There are two serious misunderstandings in modern English oral teaching. The application of information technology is separated from the traditional oral English teaching. To a certain extent, it strengthens the dependence of these two teaching modes but ignores the combined effect between the two. Too many teachers only use spoken English as a mechanical dialogue in the oral English teaching, and they are not used as a language tool for daily communication. According to the above analysis, the problems that exist in the current oral English teaching can be summarized as follows:

1. Too rigid. Rejects multi-media teaching technology and carries out the oral English training according to the traditional teaching ideas. Students lack vividness and fun when they are training or receiving oral skills. Over time, they will have a dull and boring feeling, which will bring about teaching effects.

2. Too much reliance is on multi-media technology, and extensive use of multi-media technology can make the classroom a full-fledged classroom. Too often the teachers seen caused by the multi-media tend to neglect the improvement of their own teaching level, neglect the purpose and goal of teaching, that ultimately leads to teaching. The effect is counterproductive.

3. Overemphasizing the importance of foreign language context, the school's foreign teacher resources have become the capital of school enrollment rather than the real teaching purpose. When conducting foreign teaching classes, it is easy to ignore the students' acceptance ability and their corresponding emotional factors.

4. Oral English teaching is too focused on classroom teaching and does not guide it well outside the school, uses it as a language, as a communication tool to learn, only pays attention to corresponding test scores, and too much emphasis on exams Master the skill while ignoring the substitution of true emotions.

\subsection{The Research and Analysis of Multiple Interaction Strategies}

The multi-interaction strategy mainly refers to the integration of all factors that are conducive to the optimization of the development of things, and the integration of corresponding factors at the right time to make things in this state to the extreme. In practical English teaching, pluralism mainly emphasizes the interaction between its subjects such as teachers and students, including the comprehensive interaction between teachers and students. Under the influence of information technology, multi-element interaction emphasizes the comprehensive timing of various factors and the comprehensiveness and hierarchy of the factors involved. In English teaching, teachers as the incentive under the multi-interaction strategy need to take the initiative to guide. To encourage students to learn English, students as recipients need to actively adjust various functions, and actively try to find ways to improve. This section will analyze the conceptual 
model of the multi-interaction strategy and give its specific operational flow.

\subsubsection{The Model of Multiple Interaction Strategies}

In actual teaching, teachers, and students say that the accompanying relevant factors constitute the pluralism in the multi-interaction strategy. With the introduction of the modern multi-media teaching technology, the ideal modern multi-individual teaching strategy should include three elements situational learning, cooperative learning and open learning. Teachers as a subject should actively guide students to learn and teach students as the center. design. A good knowledge state can be expressed as follows:

$$
K_{f}=K_{p}+A+H+Q
$$

Corresponding $\mathrm{Kf}$ corresponds to the knowledge level mastered by the student, and corresponding Kp corresponds to the student's mastery ability, A corresponds to the current situation, $\mathrm{H}$ corresponds to the student's mental health degree, and Q corresponds to the environment it faces.

Based on the above analysis, it can be concluded that teachers, students, content and environment are the four most important elements in multi-disciplinary teaching. The concept of the multi-interaction model is modeled. The following assumptions are made:

1. The SMD teaching module design.

It is mainly a unit that constitutes the entire teaching system. It is separate from the content and object of teaching and it is relatively independent. It can be integrated with the teaching modules of other subjects to form a higher level. For the module teaching design, this content is mainly composed of

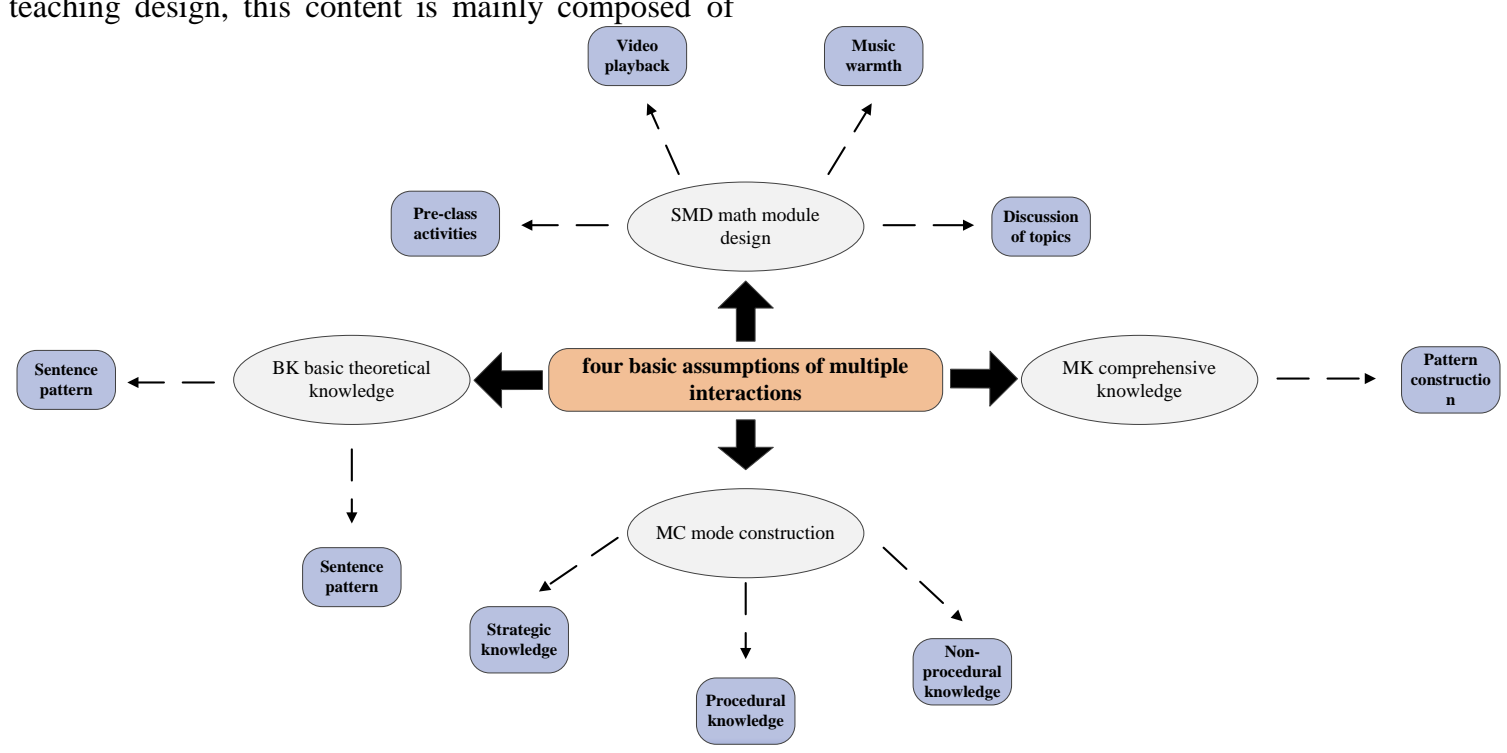

pre-class warm lesion activities, video playback, music warm-up, and topic discussion, etc.

2. The BK basic theoretical knowledge.

It mainly emphasizes the explanation of the irreplaceable knowledge in the teaching process, such as some basic concept nouns and conventions, sentence patterns and so on.

3. The MK comprehensive knowledge.

It is mainly implemented for foreign language learning, which needs to consider the culture of the language country and the corresponding context, which needs to be realized in a comprehensive context. Its specific breakdown includes strategic knowledge, procedural knowledge, and nonprocedural knowledge.

4. The MC mode construction.

It mainly refers to the process of combining multiple modules and applications, which can soften more new technology and ideas. Finally, the modelbased construction can form an intuitive and complex knowledge system, which can completely map the entire teaching. profile.

The above block diagram of the four factors and the content they contain is shown in Figure 1. The corresponding multi-interactive conceptual model is summarized in Equation 2:

$$
C M=\left(\begin{array}{llll}
S M D & B K & M K & M C
\end{array}\right)
$$

The content of the corresponding concept is expressed by formulas $3,4,5$, and 6 :

$S M D=\{S T D R \mid S T D R \quad \in$ Unit teaching mode construction $\}$

Figure 1. The Above Block Diagram of the Four Factors and the Content they Contain. 


$$
\begin{aligned}
& B K=\left\{\begin{array}{lll}
K & C K & P K
\end{array}\right. \\
& \mid K \in \text { Basic knowledge } \\
& C K \in \text { Compound knowledge } \\
& P K \in \text { Procedural knowledge } \\
& M K=\{K R \mid K R \in \text { Knowledge model construction }
\end{aligned}
$$

$M C=\{S T D \mid S T D \in$ Knowledge model construction

The above mathematical formulas and corresponding block diagrams basically define the conceptual hypothesis of applying the multi-media technology for teaching under the condition of the multiple interactions, thus constructing a multi-media multi-interaction teaching model, which basically covers the behavioral teaching theory and the cognitive teaching theory. The corresponding constructivist teaching theory, while in the process of understanding and implementing the model, teachers need to give full play to their subjective initiative, and students need to exert their enthusiasm. Both parties need to fully understand the relevant conceptual models in the dynamic implementation process.

The above is more abstract when discussing the four major factor models. Section 3 will discuss the practical operation of the multi-individual teaching strategy.

\subsubsection{The Practical Methods of Multiple Interaction Strategies}

The teaching under the multi-interaction strategy is to mainly summarize the four steps, namely, the sufficient design before the task, the environment creation, multiple interaction links and timely evaluation feedback. However, when the actual operation is carried out in detail, the four major steps can be adjusted and transformed. The corresponding operational flow diagram is shown in Figure 2. In the figure, the teacher as the main body under the whole strategy needs to conduct the actual analysis according to the teaching purpose. The so-called SLS work is carried out and the students need to actively cooperate with the teacher in the classroom. At the same time, they need to interact in time in the classroom with the corresponding $3 \mathrm{D}$ virtual language environment. The students need to focus on the curriculum design of the teacher. The in-depth analysis should use English as a tool to learn in practice and guide practice in learning. After completing the above cooperation, students and teachers need to conduct a self-evaluation, summarization and prepare adequately for the next lesson.

According to the different strategies, the corresponding types of multi-interaction strategies are classified as shown in Table 1.

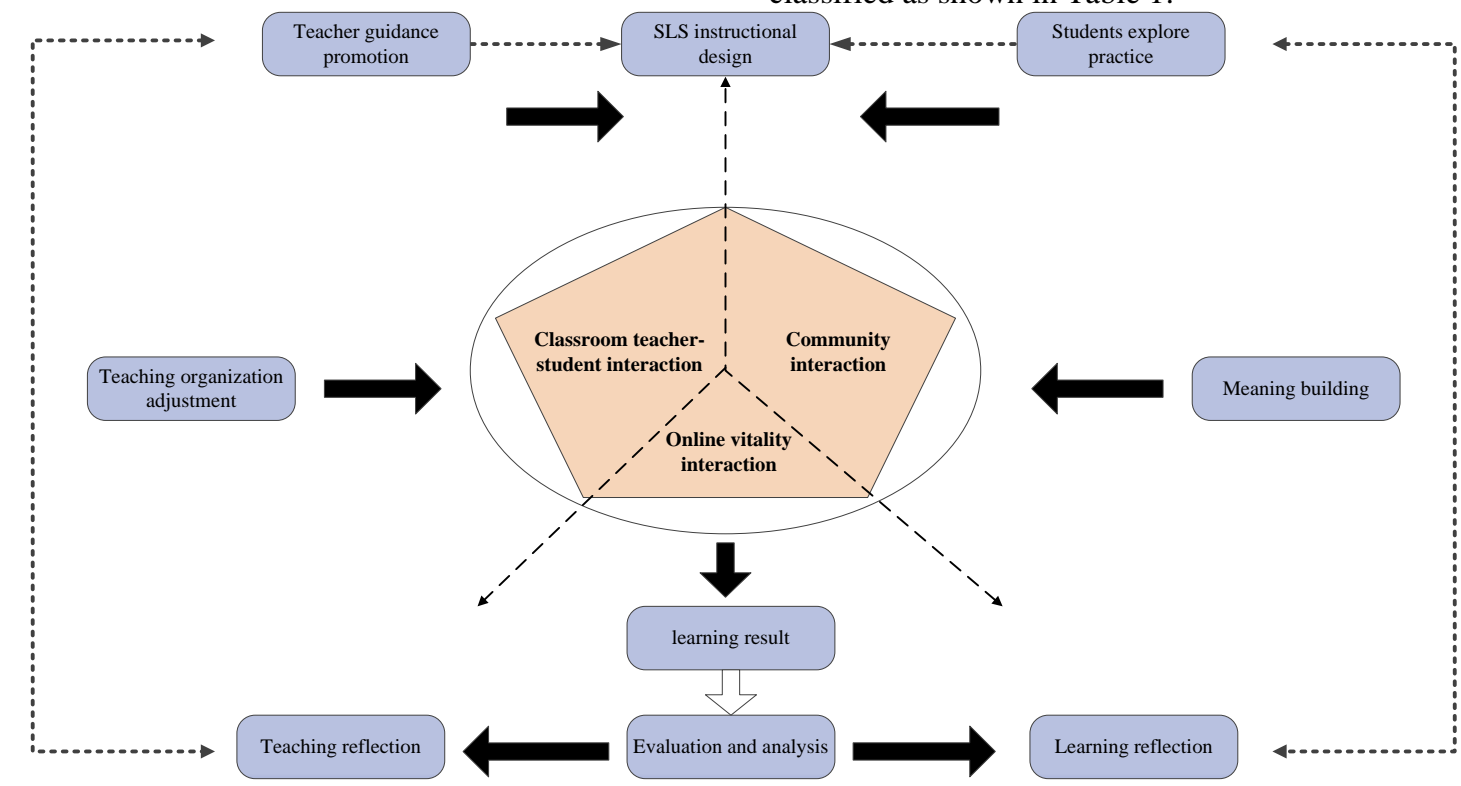

Figure 2. The Corresponding Operational Flow Diagram. 
Table 1. The Corresponding Types of Multi-interaction Strategies.

\begin{tabular}{|l|l|l|l|l|}
\hline $\begin{array}{l}\text { Interactive } \\
\text { subject }\end{array}$ & $\begin{array}{l}\text { Teacher } \\
\text { and } \\
\text { student } \\
\text { class }\end{array}$ & $\begin{array}{l}\text { Students } \\
\text { and } \\
\text { students }\end{array}$ & $\begin{array}{l}\text { Teacher } \\
\text { and } \\
\text { teacher }\end{array}$ & $\begin{array}{l}\text { Teacher } \\
\text { and } \\
\text { student }\end{array}$ \\
\hline $\begin{array}{l}\text { Type } \\
\text { example }\end{array}$ & $\begin{array}{l}\text { Teacher- } \\
\text { student } \\
\text { interaction }\end{array}$ & $\begin{array}{l}\text { Student } \\
\text { interaction } \\
\text { with } \\
\text { students }\end{array}$ & $\begin{array}{l}\text { Teacher } \\
\text { and } \\
\text { teacher } \\
\text { interact } \\
\text { outside } \\
\text { the } \\
\text { classroom }\end{array}$ & $\begin{array}{l}\text { Teacher } \\
\text { and } \\
\text { student } \\
\text { interaction } \\
\text { outside the } \\
\text { classroom }\end{array}$ \\
\hline
\end{tabular}

\section{THE ESTABLISHMENT OF THE ORAL ENGLISH TEACHING MODE UNDER MULTIPLE INTERACTION STRATEGIES}

BASED on the above-mentioned establishment of the multi-interaction teaching conceptual model, this section will specifically discuss the teaching of spoken English based on the multi-interaction strategy. Under the strategy of multiple interactions, the oral English teaching emphasizes the combination of the first and the second layer of interaction. It is not only limited to the one-way interaction between the traditional teacher and student but also forms a kind of teacher, between the teacher and student. In the interaction, the first and second layer of interaction interacts and drives each other.

\subsection{The Specific Analysis of the Interaction between the First and Second Layer}

Oral English teaching based on a multi-interaction strategy depends on the full integration of the first layer and second layer of interaction. Based on the interaction between the first layer and the second layer, a new multi-media based oral English teaching model is proposed, which focuses on the four major teaching objectives; training, maintaining students' interest in learning and learning motivation, providing learning and communication resources, and helping. Students gain learning strategies to help students solve their learning difficulties.

\subsubsection{Optimization of the First Layer of Interaction}

The first level of interactive teaching mainly refers to the simple interaction between teachers and students. In the practice of teaching, it is the classroom oral training, extracurricular oral training and oral training between people and machines after the introduction of the multi-media teaching. This paper is based on the multi-media virtual technology to optimize and improve the interaction level. The following four problems are mainly considered in the improvement:

1. The first layer of interactive teaching mode.

The introduction of the new multi-media 3D virtual environment technology enables students to practice in oral English practice in the classroom so that they are in a pure English environment, which can mobilize the students' enthusiasm, stimulate their interest, and let students feel spoken English in practice. With communication, and while making students feel their learning behavior, the corresponding comparison with the traditional blending classroom is shown in Table 2:

Table 2. The Corresponding Comparison with the Traditional Blending Classroom.

\begin{tabular}{|l|l|l|}
\hline $\begin{array}{l}\text { Blending } \\
\text { project }\end{array}$ & $\begin{array}{l}\text { Improvement of } \\
\text { this article }\end{array}$ & $\begin{array}{l}\text { Traditional } \\
\text { blending }\end{array}$ \\
\hline $\begin{array}{l}\text { Training } \\
\text { form }\end{array}$ & 3D virtual & $\begin{array}{l}\text { Simple } \\
\text { classroom } \\
\text { training }\end{array}$ \\
\hline $\begin{array}{l}\text { Training } \\
\text { situation }\end{array}$ & $\begin{array}{l}\text { Simulated entity } \\
\text { context }\end{array}$ & $\begin{array}{l}\text { Real and } \\
\text { simple } \\
\text { situation }\end{array}$ \\
\hline $\begin{array}{l}\text { Cooperate } \\
\text { with training } \\
\text { media }\end{array}$ & $\begin{array}{l}\text { multimedia } \\
\text { technology }\end{array}$ & $\begin{array}{l}\text { Mechanical } \\
\text { dialogue }\end{array}$ \\
\hline
\end{tabular}

2. The openness of the first layer of the interactive teaching mode.

In terms of openness, we must actively release the autonomy and enthusiasm of the students' learning. Therefore, in actual teaching, it is necessary to break the fixed pattern of thinking of the original traditional teaching mode. When conducting the open strategy, it is necessary to explore the active oral English teaching class actively, and actively prepare for the pre-class after-school activities. It is necessary to give full play to the leading role and actively use the multi-media technology to make up for the information gap in the students' oral English skills. In the multi-interaction and open teaching, teachers need to actively organize students to discuss in groups and share their oral English learning experience. However, in the open teaching, teachers should guide students to control self-discipline at an appropriate time, and not exceed certain limits.

3. The life of the teacher in the first layer of interactive teaching.

In this teaching practice, it is necessary to weaken the relationship between teachers and students. In the course of the oral English teaching, teachers need to be positioned as a good oral English communication partner. The success of the oral teaching often depends on the relationship between the teacher and student. In this process, teachers need to respect the personality and experience of students, actively encourage students to explore and cultivate their practical spirit, and let students actively seek ways to practice oral English and teachers need to participate in the process.

4. Diversity optimization of the first layer of interactive teaching forms.

Under the multi-dimensional interaction strategy, the diversity of the teaching form is extremely critical. It is too monotonous in the traditional teaching mode. 
It is often instilled in the same way regardless of the students' ability to accept differences. In the multiinteraction strategy proposed, it needs to be active and guide students to learn. The form should be diverse and should be fun and entertaining, so that students can speak and not be afraid of making mistakes. In this process, the main forms of access such as the multi-media teaching, situational teaching, foreign exchange and correspondence, the reading of English masterpieces and the teaching of differences in the spoken English culture. Under such circumstances, the oral English learning is more abundant, which often makes students learn English more actively and practice oral English in their daily life. The corresponding traditional and the optimized teaching mode are shown in Table 3:

Table 3. The Corresponding Traditional and the Optimized Teaching Mode.

\begin{tabular}{|l|l|l|}
\hline $\begin{array}{l}\text { Teaching } \\
\text { form }\end{array}$ & $\begin{array}{l}\text { Improvement of this } \\
\text { article }\end{array}$ & $\begin{array}{l}\text { Traditional } \\
\text { blending }\end{array}$ \\
\hline $\mathbf{1}$ & 3D virtual & $\begin{array}{l}\text { Single } \\
\text { course } \\
\text { instilling }\end{array}$ \\
\hline $\mathbf{2}$ & Foreign exchange & $\begin{array}{l}\text { Simple oral } \\
\text { training }\end{array}$ \\
\hline $\mathbf{3}$ & $\begin{array}{l}\text { English masterpiece } \\
\text { reading and problem } \\
\text { discussion }\end{array}$ & $\begin{array}{l}\text { Mechanical } \\
\text { dialogue }\end{array}$ \\
\hline
\end{tabular}

\subsubsection{Optimization of the second layer of} interaction

The second level of interaction mainly refers to the cultivation of the students' psychology, which is the so-called invisible level of interaction, including the interaction of emotions such as emotions and the corresponding physiological movements. At this level, oral English teaching is regarded as a philosophy or a combination of psychology and education. Its main theory is constructivist learning theory, situational cognitive theory and corresponding metacognitive learning strategies. The corresponding architecture is shown in Figure 3. The constructivist theory is extremely important in the second level of interaction. It can be said to be a philosophical view, which emphasizes the comprehensive construction of knowledge and the students' psychological emotions and attaches importance to the students in learning engineering with feelings and the so-called learning experience. In this, the teacher-student relationship is a harmonious and mutually supportive relationship. It emphasizes is middle school, progressing in school, and emphasizing the combined effects of the body and emotion. The corresponding data expression context cognitive theory mainly emphasizes the situational substitution in the second level, that is, let students participate in learning independently, rather than passive rebellious learning cognition. The metacognitive learning theory mainly emphasizes the students' self-seeking direction in the oral learning and finds their own suitable oral practice and development methods. The teacher only guides the students through the guidance of the independent learning and develops relevant learning plans to guide students to learn relevant skills. The habit of practicing the mechanical language creatively into a language activity.

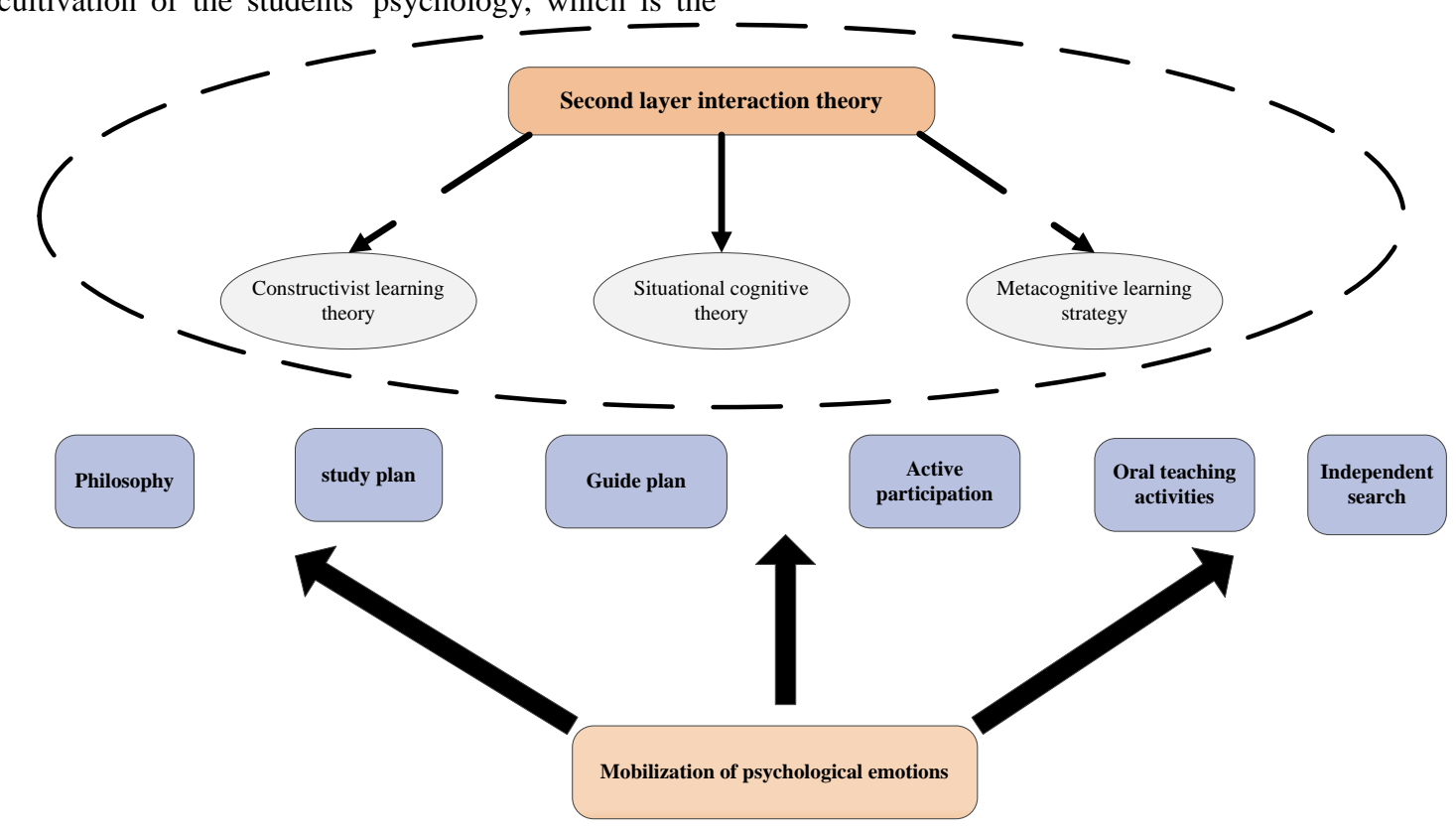

Figure 3. The Corresponding Architecture. 


\subsection{Multi-interactive English oral teaching system design}

There are several key factors that need to be met when designing a multi-interactive English oral teaching system, which are system-solved problems, system objects, and system implementation tools for system solutions.

In the system problem, this paper mainly discusses the teaching mode of spoken English. Therefore, the problem to be solved on this basis is whether the multi-interaction strategy has a significant effect on the cultivation of the students' actual oral English strategic awareness. The second is the multidimensional interaction. Can teaching promote the students' self-learning ability and cooperation ability, and whether it can provide students with a meaningful input and output English speaking environment?

In the determination of the experimental object, this paper mainly conducts experiments in the oral English of middle school students. In the experiment, the English scores of a middle school are selected for actual statistical conversion, and at the same time, the two classes are almost parallel in performance, so that the results can be discharged. The corresponding scores are shown in Table 4, and the corresponding sample is 60 people, which is divided into two samples.
Table 4. The Corresponding Scores.

\begin{tabular}{|l|c|c|}
\hline & $\begin{array}{c}\text { Sample } \\
\text { one }\end{array}$ & Sample two \\
\hline Student number & 60 & 60 \\
\hline Number of girls & 29 & 31 \\
\hline Number of boys & 31 & 29 \\
\hline $\begin{array}{l}\text { Initial average } \\
\text { score }\end{array}$ & 77.58 & 78.12 \\
\hline $\begin{array}{l}\text { Weekly speaking } \\
\text { time }\end{array}$ & 1.2 & 1.3 \\
\hline $\begin{array}{l}\text { Weekly speaking } \\
\text { practice time }\end{array}$ & 1.2 & 1.2 \\
\hline
\end{tabular}

In the actual program, it is necessary to actively select the subjects, and participate in the interaction between the students and students and the interaction between teachers and students according to the above theory of the multi-interaction, and carry out the feedback evaluation through the self-learning plan of independent learners. The main tools used in the experiments are the multi-media technologies such as the $3 \mathrm{D}$ systems, computer simulation technology and voice intelligence technology. The corresponding system interaction form is shown in Figure 4:

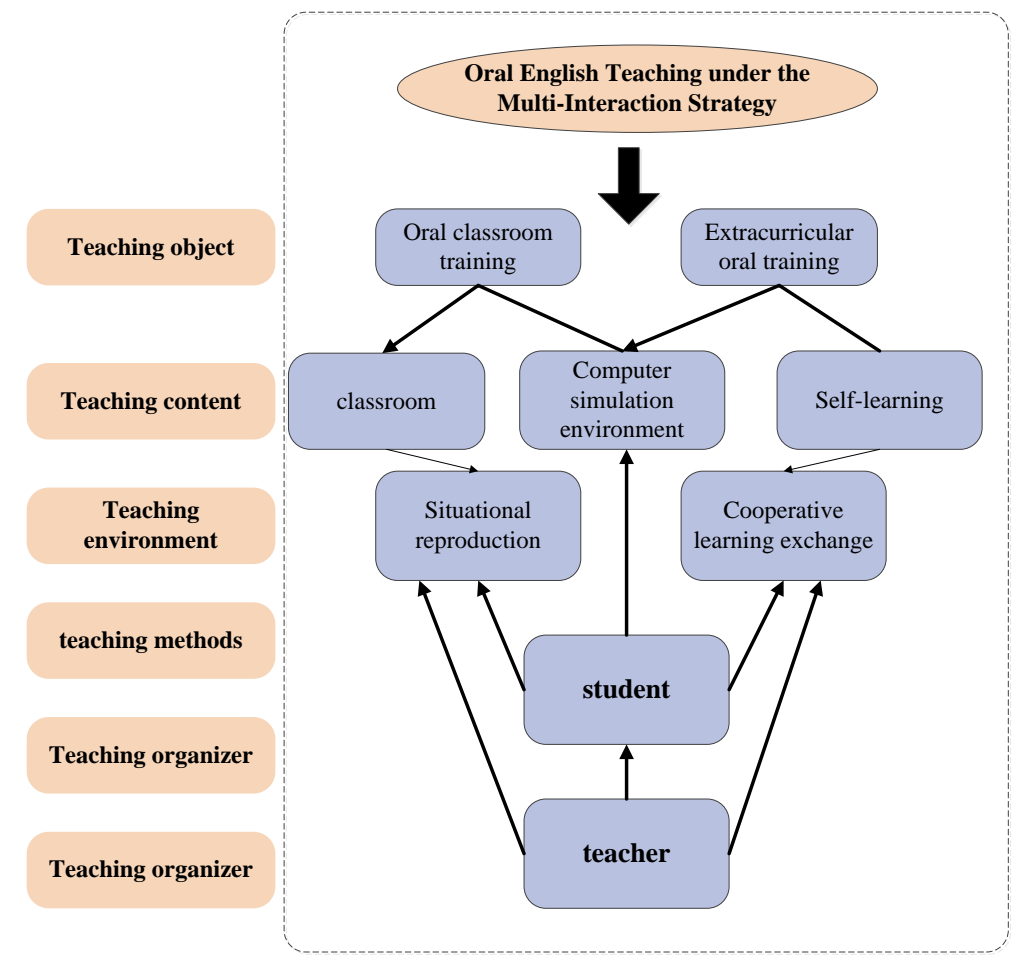

Figure 4. The Corresponding System Interaction Form. 


\section{THE EXPERIMENTAL RESULTS AND ANALYSIS}

BASED on the theory proposed, his paper conducts the actual test based on the sample data proposed in Table 4, and the corresponding test period is one month. The corresponding comparative analysis table is shown in Table 5. The experimental results clearly show that the corresponding scores are greatly improved after implementing the multi-spoken language teaching mode proposed in this paper.

Table 5. The Corresponding Comparative Analysis Table.

\begin{tabular}{|l|c|c|}
\hline & Sample one & Sample two \\
\hline Student number & 60 & 60 \\
\hline Number of girls & 29 & 31 \\
\hline Number of boys & 31 & 29 \\
\hline $\begin{array}{l}\text { Weekly speaking } \\
\text { time }\end{array}$ & 1.2 & 1.3 \\
\hline $\begin{array}{l}\text { Weekly speaking } \\
\text { practice time }\end{array}$ & 1.2 & 1.2 \\
\hline $\begin{array}{l}\text { Initial average } \\
\text { score }\end{array}$ & 77.58 & 78.12 \\
\hline $\begin{array}{l}\text { Post- } \\
\text { implementation } \\
\text { results }\end{array}$ & 85.1 & 85.9 \\
\hline
\end{tabular}

The corresponding comparison of the results before and after the line chart is shown in Figure 5.

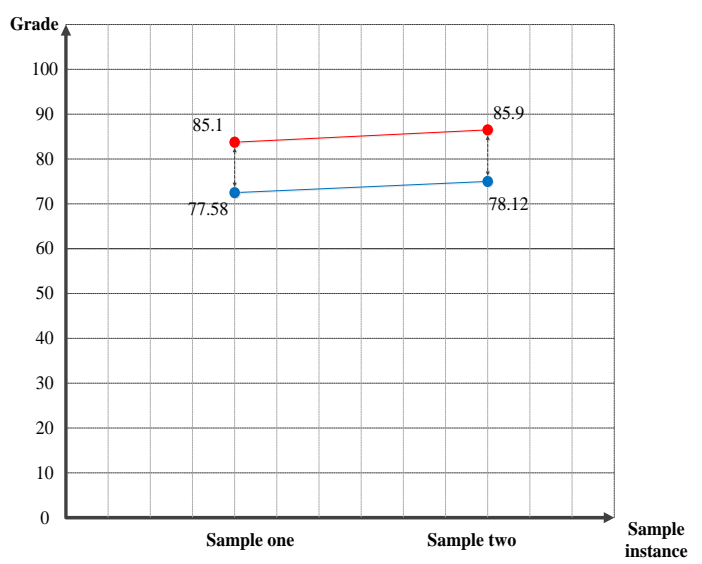

Figure 5. The Corresponding Comparison of the Results Before and After the Line Char.

Of course, only the improvement of the scores does not indicate that the oral English teaching model proposed in this paper is recognized in the acceptance degree. Therefore, this paper has made an actual questionnaire based on this. The statistical results of the questionnaire are shown in Figure 6. The results show that the improvement of most students' grades is mainly based on the self-study, and the corresponding learning interest are more intense than the traditional oral English learning mode, except for the above. In addition to the statistics, the questionnaire also includes relevant evaluations on the multi-interactive oral English teaching in this experiment. Most of the students said that this method has a strong charm to a certain extent and can guide students to learn independently. To stimulate a students' desire to learn and practice oral English, and truly use spoken English as a common practice rather than a persecution. Therefore, based on the above analysis, this paper draws a conclusion that the oral English teaching is not limited to traditional classroom learning. It should be in the real interactive link to feel the pleasure of the oral English learning and the oral English as a communication tool.

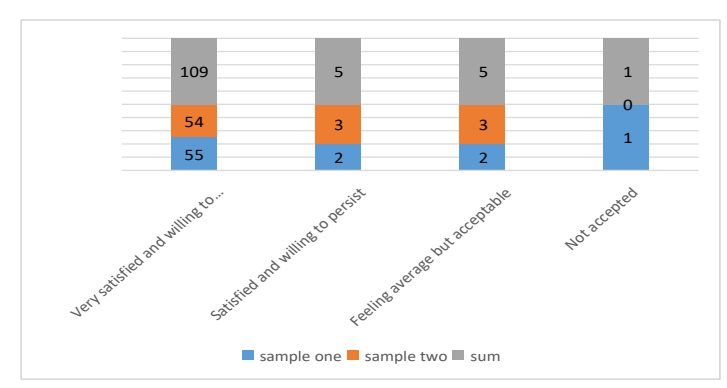

Figure 6. The Statistical Results of the Questionnaire.

\section{CONCLUSION}

THIS paper mainly analyzes the shortcomings of the traditional mode of the oral English teaching mode and the specific analysis of the theory proposed in this paper. Based on the computer technology and the development of the oral English teaching under the Chinese characteristics, this paper proposes a multiinteractive multi-media teaching mode of spoken English. The model proposed in this paper will combine the first layer of interaction in the oral English teaching, that is, the classroom and extracurricular teacher-student interaction, life-andlife interaction, and vital interaction, second-level interaction, namely teacher-student emotion, and context and motivation. In the end, this paper compares and analyzes the actual sample test of a middle school for one month. The experimental results show that the multi-interaction strategy of the spoken English is more advantageous than the traditional teaching mode.

\section{REFERENCES}

Ahmadian M J (2012). "The Effects of Guided Careful Online Planning on Complexity, Accuracy and Fluency in Intermediate EFL Learners' Oral Production: The Case of English Articles". Language Teaching Research, 16(1): pgs. 129149. 
Ahmadian M J (2012). "The Effects of Guided Careful Online Planning on Complexity, Accuracy and Fluency in Intermediate EFL Learners' Oral Production: The Case of English Articles". Language Teaching Research, 16(1): 129-149.

Alshareef F M (2016). "The Effectiveness of Using Linguistic Classroom Activities in Teaching English Language in Developing the Skills of Oral Linguistic Performance and Decision-Making Skill among Third Grade Intermediate Students in Makah.”. English Language Teaching, 2016 9(3):207-219.

Asr M, Wong A J, Fuller C D (2017). "Patterns of locoregional failure following post-operative intensity-modulated radiotherapy to oral cavity cancer: quantitative spatial and dosimetric analysis using a deformable image registration workflow". Radiation Oncology, 12(1):129-137.

Carruthers P, Skead N K, Galloway K (2012). "Teaching Skills and Outcomes in Australian Property Law Units: A Survey of Current Approaches". Social Science Electronic Publishing, 12(2):356-369.

Huang, D; Bai, Y; Liu, J, C (2019). Hierarchical Optimization of Network Resource for Heterogeneous Service in Cloud Scenarios. Intelligent Automation And Soft Computing, 24(4):883-889

Jiang W, Zhang J, Lv X (2018). "Continuous tube feeding versus intermittent oral feeding for intermediate position enterostomy in infants". Asia Pacific Journal of Clinical Nutrition, 27(2):313317.

Kon K, Shiota M, Sakuyama A (2017). "Evaluation of the alteration of occlusal distribution in unilateral free-end and intermediate missing cases". Journal of Oral Implantology, 43(1):3-7.

Oli A N, Nweke J N, Ugwu M C (2013). "Knowledge and use of disinfection policy in some government hospitals in south-east, Nigeria". Applied Physics Letters, 35(9):656-658.
Omitola O G, Soyele O O, Sigbeku O (2017). “A multi-centre evaluation of oral cancer in Southern and Western Nigeria: an African oral pathology research consortium initiative". Pan Afr Med J, 28(6):8-13.

Russo R, Edu A, Seta F D (2018). "Study on the effects of an oral lactobacilli and lactoferrin complex in women with intermediate vaginal microbiota". Archives of Gynecology \& Obstetrics, 9(4):1-7.

Shirato J, Stapleton P (2007). “Comparing English Vocabulary in a Spoken Learner Corpus with a Native Speaker Corpus: Pedagogical Implications Arising from an Empirical Study in Japan". Language Teaching Research, 11(4):393-412.

Stengers H, Boers F, Housen A (2011). "Formulaic Sequences and L2 Oral Proficiency: Does the Type of Target Language Influence the Association?". IRAL - International Review of Applied Linguistics in Language Teaching, 49(4):321-343.

Symeonidis C, Matsou A, Tzetzi D (2017). "Amblyopia due to intermediate uveitis as the presenting symptom of Crohn's disease in a 6year-old boy". Journal of Aapos the Official Publication of the American Association for Pediatric Ophthalmology \& Strabismus, 21(6):6678.

\section{NOTES ON CONTRIBUTORS}

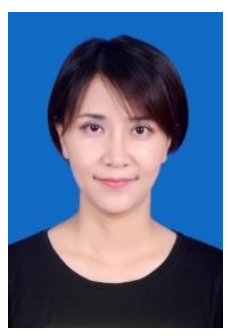

Na Li. Master of Arts, Lecturer. Graduated from Xi'an International Studies University in 2009. Worked in Shaanxi Xueqian Normal University. Research interest are discourse analysis. 